\title{
Value models: Finance, risk, and political economy
}

\section{Brett Christophers}

Uppsala University, Sweden

\begin{abstract}
This article develops a basic typological framework for understanding and analyzing financial risk from a political economy perspective. It is motivated by growing awareness of the contemporary significance of financial risk and by the fact that the political-economic literature on such risk currently lacks a workable heuristic. The framework distinguishes between and fleshes out what I refer to as the principal 'value models' of finance: fees, gains, premia, and spreads. Its primary aim is to facilitate the identification and conceptualization of: (1) the different risk configurations characterizing the heterogeneous political economy of finance; and (2) the different ways in which key stakeholders - such as finance capital, non-financial capital, and labor - come to be enrolled in such configurations. It also aims to contribute to the wider project of demystifying not just financial risk in particular but modern finance more generally.
\end{abstract}

\section{Keywords}

Value, finance, risk, political economy, capitalism, finance capital

\section{Introduction}

The global financial crisis that began in 2007 was, amongst other things, indelibly a crisis of financial risk. It was a crisis in which financial risks - risks, for instance, of debtors not repaying borrowed monies, or of declines in the market prices of tradable assets - were realized and risk pricing and management techniques failed. It was a crisis, too, of knowledge about risk - specifically, the knowledge embedded in banks' and regulators' failed riskmanagement models. Risk, therefore, must be a central consideration in the development of critical social-scientific understandings not only of the crisis and its origins but of the "postcrisis' financial landscape too. This, however, presents something of a problem for one of the main scholarly traditions to which people have looked and continue to look for answers about finance: political economy.

\section{Corresponding author:}

Brett Christophers, Department of Social and Economic Geography, Uppsala University, Box 513, 75120 Uppsala, Sweden. Email: brett.christophers@kultgeog.uu.se 
Understood here in the 'classical' sense of a concern with the mechanisms and social relations of value creation, realization, and accumulation - as opposed to the alternative framing of 'political' (states') intervention in 'economies' (markets) - political economy has come to the question of financial risk relatively late in the day. Only since the turn of the millennium has a substantive political-economic literature on financial risk begun to emerge. This literature, furthermore, deals principally with what LiPuma and Lee (2004: 149) term "abstract risk", by which they mean financial risk in a generalized (and generalizing) form, abstracted from particular historical-geographical contexts. As such, tools or frameworks to support the political-economic study of "concrete and specific instances of [financial] risk" (LiPuma and Lee, 2004: 149) - i.e., the investigation of such risk's own distinctive political economy - are lacking.

This article proposes a rudimentary facilitative framework of this kind. It submits that one productive way of approaching the creation, realization, and accumulation of value in and through 'concrete and specific instances' of financial risk is to distinguish between and analytically unpack what it terms finance's value models. These models, summarily stated, represent the principal ways in which finance capital (i.e., capital involved wholly or primarily in financial activities) generates revenues and profits, and hence reproduces itself. The article identifies four such models, styled as fees, gains, premia, and spreads. It shows that understanding the core dynamics of these models can significantly enhance our understanding of the political economy of financial risk, not least by illuminating the requirements of each such model vis-à-vis relations between finance capital, non-financial capital, and labor, and especially regarding the distribution of financial risk among them.

But, the article also has an important secondary objective. This is to contribute towards the wider project of demystifying 'finance'. Taking its cue from the name and aims of this journal, the article proceeds from the premise that part of the reason why 'Society' has such a problematic relation with 'Finance', Main Street with Wall Street, is that the latter creates and maintains a specious distance from the former by enveloping itself in a cloak of mystification: finance is irretrievably complex; only experts can begin to understand it. While certain aspects of contemporary finance are indeed extremely complex, others are not, or at least should not necessarily be conceived as such. This article's particular contribution is to demonstrate that however complex and mystifying a financial product or service may appear, its politicaleconomic logic can invariably be distilled into one or a combination of the four basic value models under consideration. Such a contribution is, note, political-economic in more sense than one, for the discourse of complexity that surrounds contemporary finance clearly has a politics - keep out of affairs you do not understand - as well as a distinct poetics (see Christophers, 2009).

The article begins with a discussion of the place of financial risk in the political economy tradition. Specifically, section one substantiates and expands upon the aforementioned observation that risk has typically been peripheral to political economists' concerns, and that where it has been studied it has largely been as an abstract rather than concrete phenomenon - hence the need for a framework for approaching the political economy of financial risk in a more concrete sense. The following four sections - one for each value model - elaborate such a framework. These sections do not present empirical findings or make empirical claims, although they do draw selectively on empirical examples in order better to illustrate the ideas being presented. The article is, in other words, a conceptual one; the framework it proposes is essentially heuristic and typological. The article ends with a brief conclusion that reflects on the possible value of the proposed framework. 


\section{Financial risk in political economy}

In pre-twentieth century political economy, financial risk is notable only for its absence. The 'classical' British political economists (Adam Smith, David Ricardo, Thomas Malthus) had nothing of substance to say on the matter. Smith, for instance, made merely passing mentions; people owning property without insuring it did so ordinarily, he conjectured, out of "mere thoughtless rashness, and presumptuous contempt of the risk" (Smith, 1778: 133). Perhaps the business of finance in general, and insurance in particular, was simply too small-scale in his day to merit the attention. Certainly the contrast with today is evident in his remark that "though many people have made a little money by insurance, very few have made a great fortune" (Smith, 1778: 133). Marx, in his critique of classical political economy, might have been expected to have more to say about risk. By the mid-nineteenth century, finance was already much bigger business. And, accordingly, in the final volume of Capital, Marx (1981: 678) examined finance in greater depth than any of his predecessors, marveling at bankers' "fabulous power" in relation to non-financial capital. Yet risk per se was still neglected.

Nor did financial risk fare much better in twentieth-century political economy of a Marxian bent. In general, finance was relegated to the conceptual sidelines. In this respect conceptual developments mirrored real-world economic ones: having become even more pronounced in the final decades of the nineteenth century and the first two decades of the twentieth, the power of finance attested to by Marx was then rapidly and substantially curtailed, and it did not begin to grow again until the final few decades of the latter century (see Arrighi, 1994). ${ }^{1}$ Mid-century Marxist political economists therefore gave short shrift to finance and, with it, to financial risk. But even the great texts of Marxist political economy written during the twentieth century's two periods of financialization, and which did underscore the significance of finance - most notably Hilferding's Finance Capital (1910) towards the end of the first such period, and Harvey's The Limits to Capital (1982) at the outset of the second - did not specifically consider the political economy of risk.

Instead, where twentieth-century political economy was concerned, it was left to scholars working outside the Marxian tradition to afford financial risk greater consideration. Arguably the most important of these was the institutional economist Thorstein Veblen. Most discussion of Veblen and risk is preoccupied with his conceptualization of capital and value. In contrast to Marx's production-centered theory of capital, Veblen focused on assets. The ambition of finance, as he saw it, was to augment the capital value of a business' assets, which was calculated on the basis of their capitalization - i.e., discounting expected future income to the present. The significance of risk herein was that expected future income, and hence present value, had to be adjusted for it. But this was, in LiPuma and Lee's (2004) terms, risk in the abstract; and it was risk (the array of risks faced by business) in a general sense, including financial risk yet not limited to it.

Much less commented on, however, are Veblen's thoughts on financial risk per se, which assume a more concrete guise. He elaborated these in The Theory of Business Enterprise (1912). His chief claim was that in its dealings with non-financial corporations, finance capital - whose business he referred to as "traffic in vendible capital" - assumed much less financial risk than was commonly assumed: "What speculative risk there is in these lines of business is incidental, and it neither affords the incentive to engaging in these pursuits nor does it bound the scope of their bearing upon economic affairs" (Veblen, 1912: 166-67). Those engaged in 'ordinary' (non-financial) lines of business took just as much risk, and frequently more.

How did Veblen explain this state of affairs? His argument was suggestive - we will encounter echoes of it later - but limited. Two factors struck Veblen as pivotal. First, finance 
capital reduced its own financial risk by systematically transferring it to counterparties, in Veblen's case non-financial corporations: "the manipulations involved in this traffic in vendible capital commonly impose increased risks upon the business concerns engaged in industry" (1912: 166). The business of the latter, he went on: "is rendered more hazardous than it might be in the absence of this financiering traffic in vendible capital. The manipulations carry risk, not so much to the manipulators as such, as to the corporations whose properties are the subject of manipulation" (Veblen, 1912: 166). Because "the manipulators commonly own but a relatively small proportion of the properties involved or touched by their manipulations, the risks which arise do not fall chiefly on them" (Veblen, 1912: 167). Second, and of prime importance, finance capital could, to a significant degree, predict and thus accommodate the risks occasioned by its activities. Veblen (1912: 167) put it like this: "the manipulators have the advantage of being able, in great part, to foresee the nature, magnitude, and incidence of the risks which they create". Its counterparties could not.

Meanwhile, effective intellectual ownership of the question of financial risk was in the process of being secured outside of the political economy tradition, within the increasingly hegemonic field of mainstream (and especially financial) economics. In particular, Frank Knight's (1921) famous conceptual distinction between risk and uncertainty set the historical stage for twentieth-century finance's approach to the problem of conducting business in the face of an uncertain future: Knight proposed that while uncertainty entailed random outcomes with unknowable probabilities, risk described random outcomes with knowable probabilities. Those with the ability to calculate and put a price on such probabilities - to 'foresee' the future framed by risk - could reap enormous profits (see Markowitz, 1952). Although modern finance has moved far beyond Knight's simple calculations of probability, the basic Knightian distinction between risk and uncertainty continues to animate it. Risk can be calculated and controlled. Such, at any rate, was the pre-2007 orthodoxy. Indeed, prior to the recent financial crisis, the 'successful' isolation, pricing, and trading of financial risk was seen by many as the signal accomplishment of free-market capitalism.

If, in the wake of the crisis, there is a need for political economy to wrest control of financial risk's narration from a discredited economics mainstream, or at least to offer a credible alternative perspective, then encouragement is available in the important groundwork laid since the turn of the millennium. Political economy has 'discovered' financial risk in earnest (see, especially, Bryan and Rafferty, 2006; LiPuma and Lee, 2004; Martin et al., 2008; and Sotiropoulos et al., 2013).

That financial risk should finally have become an issue of central concern for political economists is unsurprising. In a financialized world, financial risk is everywhere; it would be difficult, and surely remiss, to ignore it. Indeed, the ubiquity and generalized importance of financial risk represents one of the three main themes of the literature in question. Not only, in fact, is risk everywhere and in everything, "systemic, enveloping everyone" (Levy, 2012: 20); it has also become a connecting thread that links all things and places to one another, rendering them subject to the same normalizing financial logic. This is the aforementioned abstract risk: "objectifying different, globally distant, and incommensurable social relations as a single priced thing" (LiPuma and Lee, 2004: 3), such that risk should be seen, as LiPuma and Lee submit, as "an overarching objectification of the totality of relations" (p. 149), wherein "capitalist social relations are no longer mediated only by labor but by risk" (p. 126) - a claim arguably implicit, if not explicit, in Veblen. For LiPuma and Lee, as for Bryan and Rafferty (2006), the quintessential expression of abstract financial risk, insofar as it aggregates particular risks in an abstract form, is the derivative. Uniquely effecting across both space and time the commensuration function alluded to by LiPuma and Lee, derivatives "combine in a 
single instrument an objectification of risk and a means of leveraging that risk" (LiPuma and Lee, 2004: 125).

The second, equally important theme of the latter-day political economy literature on financial risk is that such risk is not innate. It is something that is created, typically by the institutions of finance capital. Thus, far from seeing financial risk (as mainstream perspectives tend to do) "as a 'primitive' - an object whose origins lie outside the financial system", political economists regard such risks, Ashton (2011: 43) observes, as endogenous, crystallized specifically by the issue and circulation of various forms of credit. This perspective helps to explain the massive expansion of financial risk in recent decades. To use Knight's terms, therefore, risk is not a counterpart to uncertainty so much as "uncertainty commodified" - something actively and productively derived from uncertainty by "putting prices on future unknowns" and hence "bring[ing] imagined futures into the realm of the market" (Green, 2000: 82). Such derivation enables abstraction and commensuration, a core premise of modern finance always having been that "idiosyncratic financial uncertainty could be transformed into fungible globules of risk" (Wigan, 2010: 110).

Third and finally, attention has been directed to the (re-) distribution of financial risk. Financial risk is not only unevenly shouldered but gets moved around, with all sorts of distributional consequences of acute significance to political economists. This movement can occur in various ways. As Veblen remarked, active risk transfer is fundamental to the work of finance capital. Thus, Guyer (2009: 215), observing the proliferation of financial instruments designed to accomplish risk transfer from one party to another, accordingly asks: if "risk is 'transferred' not eliminated ... From whom and to whom is it transferred? Since mitigation can only ever be partial, where is the excess located?" But, financial risk also moves in response to wider political-economic transformations. Decades of deregulation, privatization, and trade liberalization have resulted in "the systematic shifting of risks toward those who cannot afford them, cannot control them, and do not want them" (Prasch, 2004: 405; cf. Curran, 2015). What Hacker (2006) calls 'The Great Risk Shift' has enabled the state and employers to transfer historic risk-based obligations, such as for pension provision, to workers, who are now tasked with 'embracing risk' (Baker and Simon, 2002). Such developments lead Martin et al. (2008: 121) to depict financialization as a "central conduit of risk shifting and social change" in contemporary capitalism (cf. Johnson, 2013).

In sum, much has been learned in a relatively short time. And yet, for the most part, the literature summarized above is an abstract one. It is abstract in two related senses. First, its concern is mainly with abstract financial risk, which is to say, the "objectified form of global social connectivity" delineated by LiPuma and Lee (2004: 145). Second, it maps reconfigurations of the actual concrete landscape of financial risk at a macro scale - Hacker and Prasch's 'risk shifts' being precisely 'great' ones (which is to say, ones abstracted from more definitively demarcated historical, geographical, and social coordinates). There are, to be sure, exceptions, as there always are. Exemplary political-economic studies of what LiPuma and Lee (2004: 149) call "concrete and specific instances of [financial] risk" include, but are not limited to, Ashton's (2011) examination of the reconfiguration of credit risk in crisiswracked US mortgage markets, and Johnson's (2013) analysis of the insurance industry's use of catastrophe bonds to displace financial risks associated with climate change into the broader capital markets. These, however, are exceptions to the rule. Furthermore, for all the insights into the particular political economies of risk that they generate, they do not provide a way of approaching such political economies systematically, nor of analytically connecting up the types of studies of which they are, themselves, examples. All this to say, they provide no way of reading across risk instances or of understanding one in relation to another. 
There is value, then, in considering what a useful analytical framework for enabling a systematic political-economic approach to, and relational understanding of, concrete financial risk might look like. Such a framework would not eschew questions of abstract risk altogether. As LiPuma and Lee (2004: 149) stress, the abstract and the concrete are not "two types of risk, but two inseparable dimensions of risk". Concrete risk always implies abstract risk. To concentrate on the former as opposed to the latter, therefore, is to change emphasis rather than research object.

In a crucial sense, a framework to help analytically parse financial risk is at the same time necessarily a framework to help parse finance in a wider, more general sense. This is simply because risk is a significant part, perhaps even the essence, of what finance 'is' and 'does'. Risk, as Green (2000: 78) puts it, is "the central coordinating mechanism for financial actors". It both "configures worldviews", thereby providing cognitive stability, and "structures actions", constituting the pivotal locus of value and profit opportunities for the actors in question (Green, 2000: 78). Risk is, in short, finance's stock-in-trade: amongst other things, financial firms create it (by managing the issue of risk-bearing assets), assume it (through investment in such assets), relieve other actors of it (though insurance), and enable it to be traded (by making markets in financial assets). If we can get a handle on financial risk in its concrete manifestations, then we can also at the same time get a handle on - and demystify - finance.

Of course, heuristic and typological frameworks for apprehending and parsing finance already abound. One common approach is to differentiate between types of financial institutions. By this way of thinking, distinguishing commercial banks from investment banks, mutual funds, insurers, and the like is a way of meaningfully disclosing the substance and heterogeneity of finance. Another approach is to categorize by function. This approach comes in both traditional and more innovative forms. The traditional approach is exemplified by, for instance, Menkhoff and Tolksdorf (2000), who distinguish five primary financial functions: control, funding, information, insurance, and payment. More innovative approaches take these stock functions - among which intermediation would usually be included - and add to them functions associated with more specifically contemporary financial practices such as, in particular, securitization. 'Bricolage', for example, has in this way entered the lexicon of modern financial functionality. For Engelen et al (2010: 54), bricolage denotes both the activities of those intermediary "bricoleurs" implicated in the "fragile long chains" resulting from asset securitization, and those chains themselves.

Such frameworks, however, each have their own respective individual drawbacks. In the case of the former, for example, it turns out that the harder one tries to nail down the essence of a particular 'type' of financial institution (say an investment bank), the more stubbornly it resists such stabilization, invariably spilling over the arbitrary boundaries thus drawn. Investment banks operate hedge funds; insurers are also major investors; and so on and so forth. Ultimately, one cannot segment and methodically analyze institutions on the basis of categorizations and boundaries that they themselves do not respect.

More importantly, such frameworks represent blunt instruments for political-economic analysis because they provide limited or no leverage in unpacking the property at the nub of political economy: value. Consider, by way of example, frameworks based on financial function. Since the emphasis of these is squarely on observed functionality and what is, literally, done, the dynamics of value - which of course need not correlate in any way with variance in financial function - are reduced to a secondary consideration at best. What is needed instead is a framework to help in understanding systematically the creation, realization, and accumulation of value where this occurs, in our case, specifically in and through the creation 
and exploitation of "concrete and specific instances" of financial risk - that is, a framework to help in demystifying the characteristic ways in which finance capital uses risk to expand and reproduce itself. The following sections, which identify finance's four characteristic value models, aim to provide such a framework.

\section{Value model 1: Fees}

The first (alphabetically) of finance's value models is the simplest: to charge fees for services rendered. It is in operating this model that the finance sector approximates most closely to other sectors of the economy. Or, to put it the other way round, it is in this regard that the finance sector is least distinctive. The value model is essentially that which we see in cutting somebody's hair or fixing their car for payment - the client pays for any number of reasons, including lack of expertise, resources, time, or willingness to perform the service themselves.

The range of finance-sector functions that adopt - in part or in full - this value model is practically unlimited. We see it all the way from the most basic to the most complex of services. At one end of the spectrum, for instance, there is currency exchange. Fees (often labelled commissions) are certainly not the only way that financial institutions make money from such exchange, but they are an important one. At the opposite extreme, take a business area such as prime brokerage. Dominated by investment banks such as Credit Suisse, Goldman Sachs, and Morgan Stanley, prime brokerage entails the provision of a suite of services to other sets of financial institutions, hedge funds prominent among them. These services include, but are not limited to, securities clearance, custody, and lending - the key 'value-added' being that these services are centralized, making it easier for clients to deal simultaneously with several brokers without having to manage issues such as collateral and margin independently with each one (collateral requirements, for example, are netted by the prime broker across all deals/brokers). The critical point here, however, is that client payment is largely in the form of fees.

Such fees can, of course, be structured in all manner of different ways. It can be a flat fee: the monthly fee that small businesses (but not, typically, retail customers) are usually charged for the administration of their bank current accounts, for example. It can be scaled according to transaction size. In the prime brokerage context, for instance, clients borrowing securities from their prime broker, with a view typically to short-selling them, will usually pay a fee calculated as a percentage of the value of the loaned securities. Or the fee might be performance based. Indeed, this is one respect in which hedge funds generally differ from other fund management institutions. Where conventional fund managers charge an annual management fee based on the sum invested, hedge funds negotiate performance fees as well as management fees. This, too, has obvious parallels in the 'real' world - many real estate agents will negotiate for higher marginal fee percentages on sale values above stepped thresholds.

In terms specifically of value and its accumulation, this model could not be more transparent: the service provider accrues value if fee revenues outstrip the costs incurred in service delivery. But, beyond that headline equation, things often become considerably murkier, not least in relation to the issue of who is actually paying the fees in question - an issue that brings the social relations of value and risk squarely into view. For, most significantly, it is not always clear who is paying (and bearing risk), and in what proportions. This, indeed, is in the nature of value. Consider labor. Sometimes labor pays fees directly to financial capital, in the form, for example, of overdraft fees or the fees incorporated into 
pension-fund management schemes. But often labor is arguably paying even if it is not aware of the fact. Think of the fees that non-financial corporations pay to investment banks for advising them on mergers and acquisitions. Certainly, it is the corporations themselves that pay such fees in the most direct sense. But is it not conceivable that all or some of such fees effectively are taken out of the wages paid to labor and/or are folded in to the prices for goods and services charged to laborers-as-consumers?

An empirical illustration can best make the point. The international commodities producer Glencore acquired the Canadian grain handler Viterra and the international mining company Xstrata in December 2012 and May 2013 respectively. Tucked away deep inside the full-year 2013 accounts of the resulting conglomerate - GlencoreXstrata (2013: 144-5) - are details of the fees Glencore paid to its financial advisors on these deals, totaling nearly a quarter of a billion dollars: in relation to Viterra, $\$ 54 \mathrm{~m}$ in 2012 ("professional advisors and other expenses") and \$83m in 2013 ("professional/advisors' fees and restructuring expenses"); in relation to Xstrata, $\$ 98$ m ("professional/advisors' fees"). Meanwhile, the month after the Xstrata acquisition, 1,000 workers at three of the company's chrome mines in South Africa were fired for taking illegal strike action; and three months later the company closed its mine in Collinsville, Australia for four months over a dispute with local unions. Were the investmentbank advisory fees paid in the Global North entirely disconnected from the conflicts with labor in South Africa and Australia - one-off costs in one part of the business borne without implication for continuing costs in another part? Perhaps, but perhaps not.

More generally, and turning more explicitly to the question of risk, three crucial structural considerations pertain to the fees value model. The first is that it is a very low-risk model. Often, indeed, the risk is essentially zero. Performance-based fees, which do expose the fee recipient to a measure of risk, are the business exception rather than the rule. The risk is located predominantly elsewhere: with those, for example, who pay their pension-fund management fees year-on-year, often with limited visibility of the quantum of such fees and with little to no awareness of the likely outcome (the risk being, of course, that the value of the invested assets does not go up). Hence periodic calls (as in Flood, 2014) to replace 'heads we win, tails you lose' management fees with more symmetric fee structures in which fund managers and clients share both upside and downside. In the absence of such symmetry, the main risk for individual finance capitals is arguably that of clients switching to other capitals (which, notably, is not a risk for finance capital collectively).

Yet the risk of switching is actually low for all types of financial services, and this fact connects us to our second key consideration. A low propensity to switch is widely recognized, for example, in the context of retail current accounts. In the United Kingdom, GfK NOP's Financial Research Survey indicates that a representative current account holder would change banks only once every 91 years - i.e., a median of zero times (Gondat-Larralde and Nier, 2004: 157). And, while there are multiple reasons for limited switching, which vary somewhat between different services and different customer types, one is consistent and critical: the low levels of price competition in the financial services sector (Christophers, 2016). The fees paid to investment banks represent a case in point and have recently prompted the United Kingdom's financial regulator to launch a competition inquiry, which will cover corporate as well as investment banking (Noonan et al, 2015). "Although banks will argue that all fees are negotiable", observes the veteran corporate financier-turned-business writer William D. Cohan (2012), "every corporate issuer knows the rules: Initial public offerings are priced at a 7 percent fee; high-yield-debt underwriting is priced at 3 percent; loan syndications are priced at about 1 percent. M\&A deals are still priced off the 'Lehman formula,' even though there is no more Lehman Brothers". 
Third, and most importantly, the fee model is not only a low-risk and limited-competition model; it is today a substantial component of finance sector activity and vitality. This fact jars somewhat with popular impressions, which tend to associate both commercial and investment banking more with largely non-fee-based activities, such as intermediation and proprietary trading respectively. But finance capital, by its own admission, is fee-hungry, precisely because fees are low-risk; and thus in recent decades the fees model has increasingly become its strategic priority and financial lifeblood (Erturk and Solari, 2007: 375-6, 378). For two of the giants of US commercial banking - Wells Fargo and US Bancorp - fees now generate close to half of total revenues (Mullaney, 2014). Neither, for the industry leaders, is investment banking substantially different. The contribution of commissions and fees to total income at JP Morgan Chase averaged 45 percent from 2011 to 2013, creeping above 50 percent for the first time in 2013. ${ }^{2}$ But perhaps the most striking example of the modern financial institution as feegenerating machine - aside, of course, from fund managers, for whom fees represent essentially all revenues - is the credit card company American Express. Unlike other card issuers, which tend to make the majority of their money from interest, American Express focuses on fees: annual fees charged to customers and swipe fees charged to merchants. The result: In each of the three financial years beginning in 2011, as "American Express is running to minimize its exposure to interest-rate and credit risk as much as a lender can" (Mullaney, 2014), fees and commissions contribute 78 percent of its total income (American Express Company, 2013: 60). ${ }^{3}$

\section{Value model 2: Gains}

The second financial value model entails the attempt to generate capital gains: advancing a certain amount of capital in the hope that doing so will later result in a greater amount of capital. The label given to the activity of seeking such gain tends to depend on the time horizon of the actor advancing the capital. If the time horizon is short, the activity is typically referred to as trading; if it is long (or longer), then it is labelled investment. And, importantly, where the actor in question is trading or investing their own capital - as opposed to, in the case of fund management activities of various types, the capital of clients (where the value model is fees rather than gains) - the activity is given the prefix 'proprietary'.

Today, of course, the range of assets that finance capital trades or invests in for capital gains is virtually limitless. It can be very simple: a company's equity or debt security, for instance. It can be rather more complex: for example, a derivative of that underlying security, such as a forward contract (the obligation to buy or sell it at a particular price at a particular future date) or an option (the option to do the same). Finance capital's consistent concern, however, whatever the asset, tends to be with the liquidity of the markets where one can buy and sell the asset in question, which means the ease and rapidity of doing so. The risk of not being able to 'liquidize' an asset at short notice, so-called liquidity risk, is a perennial one. For the most part, only specialist institutions therefore tend to take on investment in non-publiclytraded, illiquid assets - private equity investors being the exemplars, and usually doing so both on a proprietary basis and (for fees) with third-party investor capital.

For our purposes, one of the most important qualities of the gains model is that it is herein that the greatest risk nominally lies. The reasons for this are self-evident: one needs to advance capital - i.e., put it at risk, in order to generate (more) capital, the risk being that it will lose some or all of its value. The contrast with the fees model is instructive, since in the latter case no capital is strictly necessary and none therefore can be lost. To make gains, one needs to have, in the industry parlance, 'skin in the game'. 
It is important to appreciate that investment or trading for gain has an immediate cost as well as revenue dimension, beyond the potential cost of absolute loss. This is opportunity cost and, relatedly, the time cost of capital. Much could be said about this, but the basic point is that capital invested in one place necessarily forgoes alternative investment options (opportunities). One of those is the at-least-notionally risk-free option of cash, which, because of inflation, usually pays interest. Things, of course, look rather different in a deflationary environment. As such, the basic principle behind seeking capital gains - buy cheap and sell dearer - is not quite that basic. One can sell dearer in nominal terms and still lose real value if nominal gains have not kept pace with inflation.

From a political economy perspective, it is particularly important to appreciate that the activity of seeking capital gains through trading or investment is hardly unique to finance capital. Non-financial capital can do it; labor can too, and frequently does, either directly (as in share ownership) or indirectly (through pension funds). So are we even justified in categorizing gains as one of finance's characteristic value models? We are, because of four vital differences that distinguish the gains sought and achieved by finance capital from those sought and achieved by others.

One difference is simply scale. Finance capital, specializing in this activity, does it on an unmatched scale, which is material in-and-of itself, but also for what it enables - most notably, the power to move rather than simply respond to market prices. A second difference is related to this. Finance capital has the power, uniquely, both to make the object of investment (e.g., it is investment banks that, for fees, manage issuance of debt assets, securitize them, and so on) and to make the secondary markets therein (see the section below on 'Spreads'). Third, finance capital has - or at least has the rest of society believe that it has - a particular expertise in achieving gains, which is partly why we pay fund managers fees to do it for us. And fourth, finance capital represents, paradoxically, the critical exception to the rule that one needs to advance capital in order to grow it. For, large financial institutions often do not need to put their own capital, or at least not much of it, at risk - they can trade or invest with borrowed capital, benefitting from the goodwill of the market that they are 'good' for it, and from accommodating capital adequacy regulations. The use of leverage in the gains enterprise has grown significantly in recent decades and has profound political-economic implications (MacKenzie, 2013), central among which is the matter of whose capital is ultimately at risk.

This last issue of where the risk of loss actually lies is one of several reasons to be wary of the political-economic story that is normally told about finance capital and capital gainsseeking. This has it not only that the risk is 'proprietary', but that substantive risk is actually being taken, and that this substantive proprietary risk-taking - in the service of capital gains represents a major component of what contemporary finance capital does. How else, after all, can one understand the primary line of critique of the financial sector in the wake of the recent financial crisis, where the charge was precisely that finance capital enacted what Strange (1997) had previously labelled 'casino capitalism' (e.g. Sinn, 2012) - its principal modus operandi, according to the likes of Adair Turner, the then chairman of the UK's Financial Services Authority, being risky, proprietary trading (Binham, 2010)?

In addition to the thorny question of the actual underlying locus or location of risk, two other dimensions of this dominant narrative are problematic. The first, as with 'fees' above, concerns scale. Data suggest that proprietary trading or investment is a much smaller component of the business of finance capital than is ordinarily imagined, even for those entities - i.e., investment banks - with whom this activity is most commonly associated. In other words, to reproduce themselves, such entities do not rely significantly on success in investing or trading their 'own' capital (borrowed or otherwise). Some prominent examples can 
be marshalled to make the point. For Credit Suisse, the average annual contribution of proprietary trading or investment to total group income was 12 percent from 2011 through 2013. ${ }^{4}$ For our earlier example, JP Morgan Chase, it was just three percent. ${ }^{5}$ These data are extremely difficult to square with the casino-capitalism imagery; and it is perhaps in their light that we can understand finance capital's relative equanimity regarding the introduction of the Volcker Rule in the US (limiting proprietary trading by commercial banks), whilst more threatening components of broader sector reform under the Dodd-Frank Act were successfully neutered through lobbying.

Of course, even if the gains model does not in fact dominate the business of finance capital, the results can still be catastrophic, as the financial crisis showed, if leverage is excessive and thus there is little proprietary capital to protect against significantly declining asset values. And as Crotty et al. (2010) note, trading or investment revenue was more material to overall income, for banks such as Goldman Sachs and Morgan Stanley, in the runup to the financial crisis than it has been since (cf. Erturk and Solari, 2007: 381-2). Our specific point, therefore, should not be overstated. Nevertheless, the broader implied point is worth emphasizing: that, in view of the scale and extraordinary commercial success of finance's other value models (fees, premia, spreads), finance capital does not need both or indeed either of the two main drivers of its proprietary capital gains - namely, rising markets and/or relative superiority in investment or trading versus other actors - to hold in order to be profitable.

Less ambiguity, meanwhile, pertains to the second problematic dimension of the dominant political-economic narrative. This problem relates to the notion that, in seeking gains, finance capital is indeed taking risk, irrespective of where the ultimate risk actually lies. Such a notion is central, of course, to the mythology of finance capital - the argument that high risks warrant high rewards. But we have already seen evidence, in the fees context, of finance capital gravitating away from risk; and we frequently see the same thing in regard to capital gains-seeking. One of the most noteworthy aspects of the 'post-crisis' period has been the rash of scandals to hit the financial sector, where the common feature has demonstrably been the endeavor, by and for finance capital, to minimize trading risk or eliminate it altogether. The ongoing interest-rate (e.g. LIBOR) and foreign exchange benchmark manipulation scandals are cases in point (see Ashton and Christophers, 2015). They reveal widespread, systematic, and coordinated efforts to remove the speculative risk nominally at the heart of the gains model. As Ramaa Vasudevan (2013: 10) puts it: "the LIBOR scandal is not about risky bets or bad judgment of rogue traders, but the deliberate strangling of market forces in the pursuit of profits".

All of which stands in stark contrast to the risks shouldered by the other economic actors implicated in the gains model: non-financial capital and labor. Price movements in financial markets, and the gains and losses that result, are customarily portrayed as merely responding to and not also impacting in turn the fortunes of the capitals or labors whose incomegenerating capacity the traded assets capitalize. Yet this is a truncated perspective. When company securities are rendered publicly investable and tradable, a company and its employees are rendered vulnerable to the vicissitudes of the gains enterprise. They are put at risk, and history shows that finance capital seeks gains with limited or no regard to the ramifications of its investment or trading decisions for those thus implicated. Think, for example, of shareholder decisions to accept takeover bids promising immediate capital gains but also labor redundancies, or to short-sell securities to profit from falling valuations that may markedly impair a company's ability to raise further affordable capital. If, in short, maximizing 'shareholder value' is a priority project for non-financial company managers (Froud et al, 
2000), it is all the more so for gains-seeking finance capital; and in seeking to limit the associated risk to itself the latter freely distributes it to others.

\section{Value model 3: Premia}

At its most basic, the third of finance capital's value models entails pledging to make a specified lump-sum payment to a third party in the event that said party suffers a pre-specified loss of some sort. That loss is the 'insured' loss, and in return for being financially insured against this loss - the insurance, taking the form of a monetary pay-out, being explicitly financial - the insuree commits in turn to making a series of periodic, ongoing payments. Those payments are referred to as premia, and they constitute an increasingly important source of revenue and profit for finance capital. The latter's hope and expectation is that the sums received in the form of premia outweigh the sums paid out on crystallized insurable events, with such events including death (life insurance), vehicular accidents (motor insurance), illness (health insurance), and the like. Here, then, we have arguably finance's closest thing to a one-to-one alignment between financial function on the one hand and value model on the other. Insurance and premia, to a degree, imply one another. But to critically explore the political economy of premia, value, and risk, we can begin by probing into this basic correspondence.

First of all, insurance is not only about premia, even if premia are its fundament. On the revenue side of the equation (for finance capital), gains are also an essential component of the insurance business model. Insurers represent among the most significant investors in financial markets of all sorts, investing for capital gains those received premia not (yet) required to fund pay-outs. Meanwhile, on their cost side, insurers constitute significant sources of the fees relied upon by other financial capitals. Those fees are of two main types. The first are broking fees paid as commissions to the independent brokers who send insurees their way. The second are underwriting fees paid - in the event that such insurance underwriting is not performed in-house - to specialist companies that evaluate the risk associated with potential customers, and make recommendations on premium levels accordingly.

Furthermore, insurance is not only supplied (and thus its premia are not only received) by 'insurers'. Consider some of the newer types of insurance that have become increasingly important in recent years, such as mortgage and credit card payment insurance. In these cases, the event being insured against is inability to make payments (of interest and/or principal), with insurable grounds being events such as illness or unemployment. Underlying such insurance is a crucial political-economic dynamic. Borrowing by labor, whether through a mortgage or a credit card, involves, for labor, the assumption of multiple risks, not the least of which is the risk of inability to service such debt, and the potential ramifications of this (think home foreclosure, debt collectors, and so on). Finance capital, needless to say, has historically underplayed such risk, relegating it to the metaphorical and literal small print. But it has come to recognize that it can make money from such risk by highlighting its existence - without foregrounding it so prominently as to discourage customers from assuming it in the first place - and enabling customers to insure against it. Payment protection insurance (PPI) is the result, and lenders rather than insurers are comfortably its main vendors.

It is also clearly the case that finance capital has for a long time offered counterparties ways of insuring against risk that are not 'insurance' per se, and which, for finance capital, rely largely on methods of money-making other than premia. Perhaps the prime example, where the counterparty is non-financial capital as opposed to labor, is derivatives. For example, 
signing a contract to buy - or to have the option to buy - a certain commodity at a predetermined price at a future date is a very obvious way for non-financial companies to insure (or hedge) against the risk of unfavorable future movements in the market price of that commodity. Finance capital, for its part, can and does make money on the creation and circulation of such contracts in various ways: as fees (for writing the contracts), as gains (either by virtue of favorable price movements where it is the counterparty, or by investing in those contracts traded on secondary markets), and as spreads (see below on market-making). Indeed, there are instances where it actually receives premia, too: namely, where the derivative is an option contract and the counterparty pays an upfront premium to secure the right, but not obligation, to later buy or sell. Options, in this sense, are insurance in all but name.

From a political economy perspective, the main lesson of these several aforementioned variations on the basic insurer-premium couplet is that insurance (or something very much like it) is increasingly central to the activities of contemporary finance in general; it is no longer, if it ever was, a niche space. Or, to put it another way, finance capital more and more resembles insurance capital. The key to understanding this development is risk.

How so? To fully appreciate the centrality of risk it is necessary to register what it is that the two parties - insurer and insuree - exchange in the basic insurance transaction. Money is obviously a part of the answer. But financial risk per se is also exchanged, or, perhaps better, transferred. In the absence of insurance, the actor at risk of loss bears all the financial risk the risk, for example, of having to pay for healthcare when becoming sick. By taking out insurance, she transfers this risk to the insurer, who thus receives premia in return for bearing it (and for making good on it in the event of 'loss'). The fact of this risk transfer is perhaps especially striking in the abovementioned case of debt-related payment protection insurance. For here, finance capital assumes not only the original risk of lending - doing so on the basis of calculative practices of credit-scoring and risk-pricing (Marron, 2007), to which we return below - but, through insurance-based transfer, also the risk of borrowing. In a twisted sort of double movement, the self-same underlying risk - that of the borrower not being able to pay is monetized and capitalized by finance capital not once but twice: first through tailored interest rates, then through tailored insurance premia.

Elsewhere, this transfer mechanism is much more explicit. Consider the credit default swap (CDS) instrument, which received so much negative publicity during the financial crisis. The CDS is essentially a de facto (though not de jure) insurance contract, but one where the risk transfer - i.e., 'swap' - is made overt. In the context of the financial crisis, such contracts were widely written on the infamous bundles of securitized subprime mortgage debts. Perhaps unconvinced that such bundles merited the gold-plated credit ratings they were routinely ascribed, many investors sought to transfer the risk of their investments going sour - i.e., the risk that homeowners defaulted in large numbers on the underlying loans. The CDS provided an answer. By paying regular premia to their insurers (such as American International Group), investors were able, in theory at least, to transfer or swap their exposure to the risk of default with the purchase of a CDS contract promising payout upon the materialization of this risk.

The CDS example is important also for exemplifying a further key feature of the contemporary political economy of premia: the fact that this value model configures relations between financial capitals as well as finance capital's 'external' relations with labor and nonfinancial capital. The writing and subsequent market-based circulation of CDS contracts was and is a matter of the distribution of risk within the ranks of financial capital. The same is true of so-called catastrophe bonds (Johnson, 2013), although here it is the insurer, not the investor, that is seeking to offload risk - the risk of insurees claiming on 'catastrophic' events 
- and the risk is transferred from insurer to investor rather than vice versa. To do so, the insurer securitizes this risk in the form of bonds, which investors buy and on which the insurerissuer pays a regular coupon (interest payment) as with any other bond. Only, in this case, the coupon is effectively a premium, for if the catastrophe (insurable event) occurs the original bond principal is forgiven and the insurer uses it to pay its insurees. The 'cat bond' is, in a way, the CDS in reverse - the securitization of insurance rather than the insurance of securitization - but with the same risk-transfer rationale motivating it.

Which brings us to the final important point regarding premia and the value model they constitute for finance capital - the question of the degree to which risk really is being transferred, particularly in the case that the counterparty is labor or non-financial capital. For, it is no coincidence that, on the whole, providing insurance is profitable, and confronting the question of risk helps explain why.

We referred above to the practice of underwriting. This practice of assigning potential customers to different risk categories cannot be performed without the prior, more formative work of actuaries. It is the latter who define risk categories and set pricing guidelines for each one; they consider not individual cases but overall risk levels, relying on probabilistic modelling to do so. Most significantly of all, they render risk visible and calculable. Knowing the likelihood of (most) insurable events coming to pass, they enable insurers to set premia at levels that will probably be profitable, thus rendering the risks transferred to those insurers tolerable and, as such, not that risky. In this sense, it is clear that in contracting with finance capital, the labor or non-financial capital insuree retains risk, for if the insured event happens - and its not happening is itself a perverse risk of sorts - then the actuary should have guaranteed that the insuree has more than paid for their compensation, at the level of all insurees collectively (the 'risk pool') if not at the level of the individual.

Ulrich Beck (2009) uses the concept of a 'risk-insurance calculus' to refer to this state of affairs. While for Beck this is a primarily sociological configuration, it is clearly a politicaleconomic one too, and one increasingly central to the workings of modern finance at large. There are exclusions, of course; risks that are not statistically calculable with confidence, such as terrorism-related risks, may not be insured - or, at the margin, methods such as cat bonds will be used to spread such risk. There are also more sinister, 'hidden' exclusions. PPI in the UK is the exemplar. Banks have now had to pay more than $£ 16 \mathrm{bn}$ in redress to customers to whom they mis-sold PPI policies, namely those - such as the self-employed or those with preexisting medical conditions - who are excluded a priori from making claims but were sold the insurance regardless (Lanchester, 2013). But such exclusions do not detract from, and are not necessary for, the political-economic model of premia to 'work'. It works because the risk is calculable, distributable, and allocated in kind, in exactly the sense Veblen (1912) theorized.

\section{Value model 4: Spreads}

Spreads arguably represent the financial sector value model par excellence. The classic example is commercial banking, the bread-and-butter of which traditionally has been taking deposits and making loans, though not necessarily in that order. While fees may be levied in relation to either or both of these activities, the primary means of generating profits through their exercise has always been to set interest rates relationally, ensuring that a sufficient 'spread' or 'margin' is maintained between the rate at which funds are loaned and that paid out on deposits to ensure that costs are more than covered. The label typically given to this stock commercial banking function is 'depositary credit intermediation', the bank intermediating between cash-rich depositors and cash-hungry borrowers. 
What is the actual core function here for which the spread is being earned? Intermediation is certainly one way to think of it, but another is to think of the spread-earner as a market-maker. This - to make and maintain markets by pooling supply and demand and enabling them to mutually satisfy one another - is what economically justifies the spread. Those paying it do so because the market-maker liberates them from having to find counterparties themselves, increases the range of potential counterparties, and thus, in theory at least, improves the terms of the transaction, even though a margin is being extracted. ${ }^{6}$ Indeed, in making markets, the spread-earning intermediary becomes the counterparty - to, in the depositary credit intermediation scenario, both the depositor and the borrower. Such market-making relates to the making of both 'primary' and 'secondary' markets.

By the making of primary markets, we refer to situations where assets are actually being created as well as being (re-) distributed. The flotation or initial public offering (IPO) of company shares is a good example. The investment bank handling the IPO will certainly be paid fees for doing so, but in taking on a market-making role - which in this instance means finding, and selling the new shares to, willing investors - it will also earn a spread, representing the difference between the price per share paid to the share-issuing company and the price received from third-party investors.

This example thus also highlights a second crucial axis of segmentation of the spreads model and its political economy. Unlike in the case of depositary credit intermediation, the spread earned on the IPO is not an interest rate spread; it is a 'buy-sell' spread. This may seem like a trivial distinction, but it is not, especially where risk is concerned. Profiting from an interest rate spread requires holding onto assets and liabilities to enable the interest rate differential to bear fruit over the period of interest payments being made and received. And holding entails risks, as we shall subsequently see. Profiting from a buy-sell spread is, at least in principle, a more immediate affair. Assets (and sometimes liabilities) are acquired in order to be passed on, and as quickly as possible, so that such transfers can crystallize into profit. This is not to say that no risk is assumed, but it is a subtly different risk. In the IPO case, the risk to the bank is that it will not be able to sell on all of the shares acquired from the issuer (it 'underwrites' the issue), and it is this risk that legitimates the spread.

A second and uniquely important example of primary market-making, meanwhile, is the loan-making dimension of depositary credit intermediation itself. For, as members of the Bank of England's Monetary Analysis Directorate (McLeay et al, 2014: 1) recently admitted, "banks do not act simply as intermediaries, lending out deposits that savers place with them, and nor do they 'multiply up' central bank money to create new loans and deposits". Rather, "banks create money, in the form of bank deposits, by making new loans. When a bank makes a loan, for example to someone taking out a mortgage to buy a house, it does not typically do so by giving them thousands of pounds worth of banknotes. Instead, it credits their bank account with a bank deposit of the size of the mortgage. At that moment, new money is created" (McLeay et al, 2014: 3, emphasis in original).

In contrast, the making of secondary markets concerns situations where the assets in question already exist. High-street currency exchange, another activity based on a buy-sell spread (plus any commission charged), is one example. Another is the whole array of contemporary financial markets per se. Although it is often claimed that 'market-based' financial systems have replaced 'bank-based' ones through a process of disintermediation (e.g. Boot and Thakor, 1997; Rajan and Zingales, 2003), banks are integral to the making of the markets that have nominally supplanted them (see Christophers, 2015). It is they that guarantee markets in different financial assets, by offering both buy and sell prices and 
generating profits on the spread between them. Their role here is essentially to provide liquidity - to ensure that willing buyers and willing sellers can, respectively, buy and sell especially where it is otherwise in short supply.

What, therefore, of risk in this diverse drama of primary- and secondary- market-making? And what of labor and non-financial capital in their relation to risk? One productive way to frame this issue is in terms of 'inclusion' and 'exclusion'. In a political economy where access to capital can be essential to survival (let alone prosperity), exclusion from the markets through which capital is cycled can be debilitating, whether that exclusion pertains to labor (Leyshon and Thrift, 1996) or, as the recent experience of UK small businesses shows, to nonfinancial capital (see Macartney, 2014). But the risk of being excluded is arguably no more problematic than the risk of being included on injurious terms. Consider subprime home loans. Finance capital's discourse of 'risk-based pricing' suggests that mortgagors pay rationally calculated interest rates pegged to a borrower's individual risk profile (employment history, credit scores, and so on). But Wyly et al. (2009: 39) have found that the data for US loans advanced during the pre-crisis housing boom belies such scientism: "African Americans and Latinas/Latinos approved for credit were still twice as likely as otherwise identical nonHispanic whites to wind up with high-cost loans in 2006". Spreads, bluntly stated, were discriminatory and predatory. Finance capital can ruinously include or, alternatively, exclude, because it has the power to do so, even where the state requests that it do otherwise (on this see Macartney, 2014).

Even in the absence of such explicitly predatory behaviors, mortgage finance represents an emblematic case, in the spreads/intermediation context, of risk burdens being shouldered disproportionately by finance capital's counterparties, in just the way Veblen surmised (Christophers and Niedt, 2015). As Mian and Sufi (2014: 12) have shown, the relative "seniority" of claims on the underlying asset (the home itself) is highly material in the event of house price declines and debt serviceability constraints, with the lender enjoying the "senior" claim to the homeowner's "junior" one. The upshot of this particular risk configuration, Mian and Sufi (2014: 12) maintain, is that financial markets palpably fail to fulfil what is ostensibly one of their main purposes - "to help people in the economy share risk". By explicitly protecting banks and their creditors, our present financial system "concentrates risk squarely on the debtor", the home equity possessed by the mortgaged homeowner being "much riskier than the mortgage held by the bank" (Mian and Sufi, 2014: 12).

Referencing as it does the mortgage held by the bank, Mian and Sufi's analysis signals the significance of a wider set of (at least nominal) risks that are borne by the spread-oriented market-maker: balance-sheet risks. These are the risks that arise from holding assets and liabilities on the balance sheet. They crystallize primarily in the interest-rate spread context (where, as noted, holding is necessary to earn the spread), but they are not inconsequential in the buy-sell context either. The market-maker must have something to sell in order to fulfil its essential liquidity-providing function. Such balance-sheet risks comprise two related components: the risk that assets will lose value (or liabilities will appreciate) while 'on' the balance sheet, and, relatedly, the risk that assets will be insufficient, or not sufficiently liquid, to meet liabilities when the latter fall due. Depositary credit intermediation represents the classic case of balance-sheet risk for the spread-generator, suspended as she is between the risk of loan default on one side and, on the other, that of a bank 'run'. Because deposit banks need hold reserves representing only a fraction of customer deposits (hence 'fractionalreserve' banking), they are unable to meet withdrawal requests if sizeable numbers of depositors choose to withdraw at once. Yet with state-backed depositor protection schemes, bank runs are now a rarity; that on Northern Rock in 2007 was the UK's first for 140 years. 
Furthermore, the balance-sheet risk engendered by the spreads model has in recent decades been substantially transformed by the growth of securitization, whereby untradable cash flows - e.g., loan interest payments - are converted into tradable securities. In theory, at any rate, securitization helps the originators of loans to transfer risk off their balance sheet and on to other, counterparty-capitals. Rather than 'originating-to-hold' they now 'originate-todistribute'. Post-securitization, the asset showing on the originator's balance sheet is no longer the loan - requiring funding through a matching liability - but the cash received for selling that (securitized) loan to downstream investors. Hence, in part, the label 'off-balance-sheet financing'.

But all sorts of questions surround this nominal risk transfer. Two are critical. First, where loans are sold on to investors through securitization, has (all) risk actually been transferred? Prior to the financial crisis, most observers assumed that it had been, although rogue voices, such as Rajan's (2006: 502), warned that some of the risk - and often "the most complicated and volatile portion" - was retained. The crisis proved that such warnings were well founded. Losses on securitized home loans frequently had remained with originating banks (Acharya et al., 2013). This issue of risk's distribution under mortgage securitization subsequently became a major point of contention in post-crisis US housing finance reform. Originators were determined not to make the same mistake again, and when the Dodd-Frank Act (signed into law in 2010) insisted on such lenders having 'skin in the game' by retaining a minimum five percent of default risk on securitized mortgages, they fought back. And won. The new law left it to the relevant regulators to define the scope of exemptions to the risk retention rule, and under industry pressure they substantially widened those initially proposed (Norris, 2013).

Second, if finance capital's quintessential erstwhile intermediaries have widely abandoned originate-to-hold in favor of originate-to-distribute, are they even still in the spreads business? Partly yes, insofar as there may be a beneficial spread between the interest rate paid by the loanee and that paid on to the investor in the securitized loan (though it will rarely be visible as such, with individual loans usually being bundled together in securitized packages with blended interest rates). But there may not be a positive spread, and securitization can still 'pay' even if this is so. How?

The answer lies in the first of our value models: fees. Specifically, securitization represents a privileging of and migration towards the (less risky) fees model, its exercise begetting all manner of new fee-earning roles: issuing, underwriting, servicing (processing borrower payments), and acting as trustee (representing the rights of investors and disbursing payments to them). And, vitally, the very same capitals that dominate loan origination - banks and, in the case of home loans, mortgage brokers - also dominate this new fee landscape. For US mortgage-backed securities created between 1983 and 2008, those capitals accounted for some 87 percent of issuance, 78 percent of servicing, 97 percent of underwriting, and 97 percent of trustee work (Cetorelli and Peristiani, 2012). To this fee boon it is necessary to add, furthermore, the upfront fees charged (at between 0.5 and one percent of loan value) by the same originators for processing all the incremental loans made with the cash received from investors in previous rounds of securitization - a virtuous/vicious circle which, on many readings, largely inspired the securitization trend in the first place. In sum, fees were, and are, central to securitization; and prioritizing the fees model is, for finance capital, explicitly about distancing itself from risk. Thus, commenting on the industry's pushback against Dodd-Frank's risk retention rule, Norris (2013) notes simply that "the banks like the idea of collecting fees without risking their own capital".

Indeed, and to conclude, perhaps the more fundamental risk to finance capital with regards to the spreads value model in its contemporary form is, at least theoretically, not 
balance-sheet risk at all. It is competitor risk: the risk that competitive pressures will result in narrower spreads and thus shrunken revenues and profits. But here the risk also appears to be limited. While pressure on spreads is perhaps not quite as light as it was in the famously corespective world of 1960s and 1970s deposit banking - when the '3-6-3 rule' of banking (borrow at 3 per cent, lend at 6 per cent, and be on the golf course by $3 \mathrm{pm}$ ) prevailed - the evidence suggests that the contemporary spreads business is no more competitive than the parallel fees business, whose non-negotiable conditions we touched upon above.

Partly this is by design (design being the operative word). On the New York Stock Exchange, for example, Designated Market Makers (invariably investment banks) enjoy effective monopolies by virtue of being granted official market-making franchises for given securities. In other instances, dominance emerges in a nominally competitive situation - one such being the Nasdaq, a 'dealer' market theoretically featuring "the price-setting competition of multiple market makers" insofar as it allows for free dealer entry and exit, but where in reality "free entry does little to improve the competitive nature of the market", and thus even if market-making is not quite "monopolistic" it is markedly "concentrated" (Ellis et al., 2002: 2290-1). Meanwhile, more recent research (Kiff et al., 2009; OECD, 2011) has documented comparable concentration in derivatives market-making. And, perhaps most importantly of all - given its significance to labor and non-financial capital - there is plain vanilla depositary intermediation, where for all the talk of competition, oligopoly and minimal competition remain the norm, as even mainstream observers have noted (e.g. Kay, 2012). In short, finance capital's spreads model limits proprietary risk to the (significant) extent that it eschews competition.

\section{Conclusion}

This article has laid out a framework for understanding the political economy of finance in such a way that relations of risk can be readily and productively analyzed. Its rationale for doing so was and is a simple one: that financial risk, in a concrete guise, remains undertheorized, under-studied, and therefore poorly understood from a political economy perspective. In identifying the four characteristic value models that constitute modern finance, the article has provided a broad picture of how risk typically figures in each one and what this means not only for finance capital but also for other stakeholders in financial risk-relations.

As emphasized at the outset, making forceful empirical claims was not one of the article's aims, even though I have used selected examples of real-world developments in order to demonstrate the analytical utility of the proposed value-model framework. Yet the development of robust, ultimately generalizable, empirically based and conceptually informed claims about the political economy of financial risk, following the lead of scholars such as Ashton (2011) and Johnson (2013), remains a pressing task. The heuristic framework outlined here only has value if it can contribute in some way to such a research agenda. To conclude, then, it clearly bears asking: How might this framework be 'used'? What specific issues could or should its mobilization, or critical engagement with it, lead researchers to focus upon?

One way of answering these questions is to return briefly to the securitization revolution discussed in the final section. There, we saw a number of very important things. First, we saw that securitization has profoundly transformed a value model - generating and exploiting spreads - that has conventionally been central to the financial business; originate-to-hold became, for many lenders, originate-to-distribute. We also saw that the securitization revolution entailed the increasing significance to banks of another value model: feegeneration. And, in seeing these two things, we saw that overall risk-relations were, and 
continue to be, fundamentally reconfigured, not least because risk figures very differently in each of the four value models of finance. Generalizing from this, it could be posited that by thinking specifically in terms of value models, not only do we see things that we might not otherwise have seen; we are also able to draw out political-economic implications - i.e., implications for value and risk - that would otherwise have been harder to identify.

What, then, would represent fruitful topics for empirical study using a value-model lens? Two possibilities emerge from the preceding paragraphs. One is to analyze value-model transformation - to take an individual model, for instance gains, and investigate how it has changed over time in different places. What forces have driven such changes, with what effects, and in whose risk and value interests? A second is to analyze value-model orientation - to investigate how and why different financial institutions or groups thereof have orientated themselves in different ways to the constellation of available value models in different places and at different moments in time. Why have gains been prioritized in one conjuncture, premia in another?

Independently, or together, analysis of these two sets of questions could significantly enhance existing understandings of financial risk and the political economy of finance more generally. In particular, such analysis promises to provide some of the substance and texture that is often missing from generalized accounts of socioeconomic reconfiguration and redistribution based on financial risk-shifts. If, as Curran (2015) argues, financial risk has indeed become an increasingly key source of contemporary inequality, and society is accordingly resifting into stratified 'risk classes', the types of analysis suggested here can provide empirical context and conceptual illumination. Such analysis is pressing and long overdue. A century ago, Veblen (1912) gestured provocatively at the mechanisms implicated in, and distributional outcomes of, finance capital's enterprise of risk calculation, crystallization, and circulation. A century later, when financial risk has assumed a magnitude, scope, variegation, and significance that Veblen could surely never have imagined, his provocations remain to be satisfactorily addressed.

\section{Notes}

1. To be sure, 'finance' demonstrated various signs of resurgence during the intervening period, perhaps most notably in the shape of the growth of the Euromarkets in the late 1950s and the 1960s. But the Euromarkets did not evidence a materially increased role for finance in the wider economy. As primarily inter-bank markets, they represented in large measure a case of "finance feeding finance" (Erturk and Solari, 2007: 378; see also Christophers, 2013: 163).

2. Total income taken after provisions and interest expenses. Data retrieved from: <http://www.marketwatch.com/investing/stock/jpm/financials>.

3. Based on total income after interest expenses.

4. 'Securities gain' plus 'trading account income' as a percentage of total income net of provisions and interest expenses. Data retrieved from:

<http://www.marketwatch.com/investing/stock/cs/financials>.

5. 'Securities gain' as a percentage of total income net of provisions and interest expenses. Data retrieved from: <http://www.marketwatch.com/investing/stock/jpm/financials>.

6. French and Leyshon (2004: 267-68) provide a useful overview of the core economic functions involved in financial intermediation. 


\section{References}

Acharya, V. V., Schnabl, P. and Suarez, G. (2013) Securitization without risk transfer. Journal of Financial Economics, 107(3): 515-36.

American Express Company (2013) Annual Report 2013. Available at: <http://ir.americanexpress.com/Cache/1001185312.PDF?Y=\&O=PDF\&D=\&FID=1001185312\&T $=\& I I D=102700 />$. Accessed 18 November 2015.

Arrighi, G. (1994) The Long Twentieth Century: Money, Power, and the Origins of Our Times. London: Verso.

Ashton, P. and Christophers, B. (2015) On arbitration, arbitrage and arbitrariness in financial markets and their governance: Unpacking LIBOR and the LIBOR scandal. Economy and Society, 44(2): 188217.

Baker, T. and Simon, J. (2002) Embracing Risk: The Changing Culture of Insurance and Responsibility. Chicago, IL: University of Chicago Press.

Beck, U. (2009) World at Risk. Cambridge: Polity Press.

Binham, C. (2010) Turner plan on 'socially useless' trades make bankers see red. Bloomberg News, 7 January. Available at:

<http://www.bloomberg.com/apps/news?pid=newsarchive\&sid=aKe06gsaeQ_M>. Accessed 18 November 2015.

Boot, A. and Thakor, A. (1997) Financial system architecture. Review of Financial Studies, 10(3): 693733.

Bryan, D. and Rafferty, M. (2006) Capitalism with Derivatives: A Political Economy of Financial Derivatives. Basingstoke: Palgrave.

Cetorelli, N. and Peristiani, S. (2012) The role of banks in asset securitization. Federal Reserve Bank of New York Economic Policy Review, 18(2): 47-64.

Christophers, B. (2009) Complexity, finance, and progress in human geography. Progress in Human Geography, 33(6): 807-24.

Christophers, B. (2013) Banking Across Boundaries: Placing Finance in Capitalism. Oxford: WileyBlackwell.

Christophers, B. (2015) Against (the idea of) financial markets. Geoforum, 66: 85-93.

Christophers, B. (2016) Petals not thorns: Competition policy and finance. In: Dorn, N. (ed.) Controlling Capital: Public and Private Regulation of Financial Markets. London: Routledge. 59-74.

Christophers, B., and Niedt, C. (2015) Resisting devaluation: Foreclosure, eminent domain law, and the geographical political economy of risk. Environment and Planning A, DOI: 10.1177/0308518X15610579.

Cohan, W. (2012) Wall Street turned crisis into a cartel. Bloomberg News, 9 January. Available at: <http://www.bloombergview.com/articles/2012-01-09/cohan-how-wall-street-turned-a-crisis-intoa-cartel/>. Accessed 18 November 2015.

Crotty, J., Epstein, G. and Levina, I. (2010) Proprietary Trading is a Bigger Deal Than Many Bankers and Pundits Claim. Available at:

<http://www.peri.umass.edu/fileadmin/pdf/other_publication_types/SAFERbriefs/SAFER_note15 .pdf/>. Accessed 18 November 2015.

Curran, D. (2015) Risk illusion and organized irresponsibility in contemporary finance: Rethinking class and risk society. Economy and Society, 44(3): 392-417.

Ellis, K., Michaely, R. and O'Hara, M. (2002) The making of a dealer market: From entry to equilibrium in the trading of Nasdaq stocks. The Journal of Finance, 57(5): 2289-316.

Engelen, E., Erturk, I., Froud, J., Leaver, A. and Williams, K. (2010) Reconceptualizing financial innovation: Frame, conjuncture and bricolage. Economy and Society, 39(1): 33-63. 
Erturk, I., and Solari, S. (2007) Banks as continuous reinvention. New Political Economy, 12(3): 36988.

Flood, C. (2014) End 'heads we win, tails you lose' fees. The Financial Times, 16 November.

French, S. and Leyshon, A. (2004) The new, new financial system? Towards a conceptualization of financial reintermediation. Review of International Political Economy, 11(2): 263-88.

Froud, J., Haslam, C., Johal, S. and Williams, K. (2000) Shareholder value and financialization: Consultancy promises, management moves. Economy and Society, 29(1): 80-110.

GlencoreXstrata (2013) Annual Report 2013. Available at: <http://www.glencore.com/assets/Uploads/reports_and_results/glencore/2013/GLEN-2013Annual-Report.pdf/>. Accessed 18 November 2015.

Gondat-Larralde, C. and Nier, E. (2004) The economics of retail banking: An empirical analysis of the UK market for personal current accounts. Bank of England Quarterly Bulletin, Spring. Available at: <http://www.bankofengland.co.uk/publications/Documents/quarterlybulletin/qb040203.pdf/>. Accessed 18 November 2015.

Green, S. (2000) Negotiating with the future: The culture of modern risk in global financial markets. Environment and Planning D, 18(1): 77-90.

Guyer, J. (2009) Composites, fictions, and risk: toward an ethnography of price. In: Hann, C. and Hart, K. (eds.) Market and Society: The Great Transformation Today. Cambridge: Cambridge University Press, 203-20.

Hacker, J. (2006) The Great Risk Shift. Oxford: Oxford University Press.

Harvey, D. (1982) The Limits to Capital. Oxford: Blackwell.

Hilferding, R. (2006/1910) Finance Capital: A Study in the Latest Phase of Capitalist Development. London: Routledge.

Johnson, L. (2013) Catastrophe bonds and financial risk: Securing capital and rule through contingency. Geoforum, 45: 30-40.

Kay, J. (2012) It is time to end the oligopoly in banking. The Financial Times, 8 May.

Kiff, J., Elliott, J., Kazarian, E., Scarlata, J. and Spackman, C. (2009) Credit derivatives: systemic risks and policy options. IMF Working Paper Series, 09/254. Available at:

<http://www.imf.org/external/pubs/ft/wp/2009/wp09254.pdf/>. Accessed 18 November 2015.

Knight, F. (1921) Risk, Uncertainty and Profit. New York, NY: Hart, Schaffner and Marx.

Lanchester, J. (2013) Are we having fun yet? London Review of Books, 35(13): 3-8.

Levy, J. (2012) Freaks of Fortune: The Emerging World of Capitalism and Risk in America. Cambridge, MA: Harvard University Press.

Leyshon, A. and Thrift, N. (1996) Financial exclusion and the shifting boundaries of the financial system. Environment and Planning A, 28(7): 1150-56.

LiPuma, E. and Lee, B. (2004) Financial Derivatives and the Globalization of Risk. Durham, NC: Duke University Press.

Macartney, H. (2014) From Merlin to Oz: The strange case of failed lending targets in the UK. Review of International Political Economy, 21(4): 820-46.

MacKenzie, D. (2013) The magic lever. London Review of Books, 35(9): 16-19.

Markowitz, H. (1952) Portfolio selection. The Journal of Finance, 7(1): 77-91.

Marron, D. (2007) 'Lending by numbers': Credit scoring and the constitution of risk within American consumer credit. Economy and Society, 36(1): 103-133.

Martin, R., Rafferty, M. and Bryan, D. (2008) Financialization, risk and labour. Competition \& Change, 12(2): 120-32.

Marx, K. (1981) Capital: Volume III. London: Pelican Books.

McLeay, M., Radia, A. and Thomas, R. (2014) Money creation in the modern economy. Bank of England Quarterly Bulletin, Q1. Available at: 
<http://www.bankofengland.co.uk/publications/Documents/quarterlybulletin/2014/qb14q1prere leasemoneycreation.pdf/>. Accessed 18 November 2015.

Menkhoff, L. and Tolksdorf, N. (2000) Financial Market Drift: Decoupling of the Financial Sector from the Real Economy? Berlin: Springer.

Mian, A. and Sufi, A. (2014) House of Debt: How They (and You) Caused the Great Recession, and How We Can Prevent it from Happening Again. Chicago, IL: University of Chicago Press.

Noonan, L., Binham, C. and Arnold, M. (2015) UK investment banks face competition probe. The Financial Times, 19 February.

Norris, F. (2013) Mortgages without risk, at least for the banks. The New York Times, 28 November. OECD (2011) Bank Competition and Financial Stability. Available at: <http://www.oecd.org/daf/fin/financial-markets/48501035.pdf/>. Accessed 18 November 2015.

Prasch, R. (2004) Shifting risk: The divorce of risk from reward in American capitalism. Journal of Economic Issues, 38(2): 405-12.

Rajan, R. (2006) Has finance made the world riskier? European Financial Management, 12(4): 499533.

Rajan, R. and Zingales, L. (2003) Banks and markets: The changing character of European finance. NBER Working Paper Series, 9595. Available at: <http://www.nber.org/papers/w9595.pdf/>. Accessed 18 November 2015.

Sinn, H-W. (2012) Casino Capitalism: How the Financial Crisis Came About and What Needs to be Done Now. Oxford: Oxford University Press.

Smith, A. (1778) The Wealth of Nations: Books I-III. London: W. Strahan and T. Cadell.

Sotiropoulos, D., Milios, J. and Lapatsioras, S. (2013) A Political Economy of Contemporary Capitalism and its Crisis: Demystifying Finance. New York, NY: Routledge.

Strange, S. (1997) Casino Capitalism. Manchester: Manchester University Press.

Vasudevan, R. (2013) 'Libor'ing under the market illusion. Monthly Review, 64(8): 1-12.

Veblen, T. (1912) The Theory of Business Enterprise. New York, NY: Charles Scribner's.

Wigan, D. (2010) Credit risk transfer and crunches: Global finance victorious or vanquished? New Political Economy, 15(1): 109-125.

Wyly, E., Moos, M., Hammel, D. and Kabahizi, E. (2009) Cartographies of race and class: Mapping the class-monopoly rents of American subprime mortgage capital. International Journal of Urban and Regional Research, 33(2): 332-54. 